\title{
ANGANWADI SERVICE UTILISATION IN A DISTRICT OF NORTH KERALA, INDIA
}

\author{
Anitha S. S1, A. K. Jayasree², Devaki Antherjanam $S^{3}$ \\ ${ }^{1}$ Assistant Professor, Department of Community Medicine, Academy of Medical Sciences, Pariyaram, Kannur, Kerala. \\ 2 Professor and HOD, Department of Community Medicine, Academy of Medical Sciences, Pariyaram, Kannur, Kerala. \\ ${ }^{3}$ Senior Resident, Department of Community Medicine, Academy of Medical Sciences, Pariyaram, Kannur, Kerala.
}

\section{ABSTRACT}

\section{BACKGROUND}

The Integrated Child Development Services Scheme represents one of world's largest and unique programme for early childhood development. Preschool children call for focused attention in India because India has the highest percentage of undernourished children in the world.

The objective of this study was to identify the extent of utilisation of Anganwadi services in Kannur district, North Kerala.

\section{MATERIALS AND METHODS}

This cross-sectional study was done during July 2013- June 2014 in 44 Anganwadi centres of Kannur district. The Anganwadis were selected using multistage random sampling. The information regarding Anganwadi service utilisation was collected by interviewing mothers. Data was entered using EpiData version 3.1 and analysis done using the Statistical Package for Social Sciences (SPSS) version 16.

\section{RESULTS}

The total number of preschool children studied was 456. The average number of days of supplementary nutrition in the previous month was $20.34 \pm 2.107$. Of the total three health education classes conducted in last three months, $37.9 \%$ of mothers have attended all the three classes. Vitamin A was taken at six-month intervals by $54 \%$ of children and $8.99 \%$ children had taken albendazole at six-month intervals.

\section{CONCLUSION}

The supplementary nutrition from Anganwadi is properly utilised by the beneficiaries, whereas services like health education and antihelminthics are poorly utilised. There is shortage of vitamin A supply. Measures have to be taken to improve these services.

\section{KEYWORDS}

Anganwadi, Deworming, Preschool, Supplementary Nutrition, Vitamin A.

HOW TO CITE THIS ARTICLE: Anitha SS, Jayasree AK, Antherjanam DS. Anganwadi service utilisation in a district of north Kerala, India. J. Evolution Med. Dent. Sci. 2017;6(72):5088-5091, DOI: 10.14260/jemds/2017/1106

\begin{abstract}
BACKGROUND
Integrated Child Development Services (ICDS) scheme was started to meet the challenge of providing preschool education and to break the vicious cycle of malnutrition, morbidity, reduced learning capacity and mortality. ${ }^{1,2}$ The package of services provided by the ICDS scheme include supplementary nutrition, immunisation, health check-up, referral services, health education, and pre-school education and these are delivered through Anganwadi centres. ${ }^{3-5}$ The ICDS evaluation report by Planning Commission in 2011 states that in Kerala, average days of supplementary nutrition delivery was 20 and $11.1 \%$ of children received albendazole tablet. ${ }^{6}$ The coverage of full Vitamin A supplementation in 2012 in Kerala was below 20\%. ${ }^{7}$
\end{abstract}

Financial or Other, Competing Interest: None.

Submission 31-07-2017, Peer Review 24-08-2017,

Acceptance 30-08-2017, Published 07-09-2017.

Corresponding Author:

Dr. Anitha S. S,

Assistant Professor

Department of Community Medicine,

Academy of Medical Sciences,

Pariyaram-670503,

Kannur, Kerala.

E-mail: dranithaprasanth@gmail.com

DOI: $10.14260 /$ jemds/2017/1106

\section{(c) (1) (3) $\Theta$}

\section{MATERIALS AND METHODS}

This study was part of a cross-sectional study done during July 2013-June 2014 in forty-four anganwadi centres of Kannur district to assess the prevalence of underweight among anganwadi preschool children. Sample size was obtained as 383 using the formula for cross-sectional studies taking the prevalence of underweight as $22.9 \%$ (NFHS III), with $20 \%$ relative precision and $10 \%$ non-response rate. From all the eleven revenue blocks in the district, four AWCs each were selected using multistage random sampling. The objective of the present study was to identify the extent of utilisation of Anganwadi services in Kannur district, North Kerala.

All the preschool children attending the AWC, whose mothers gave consent were included in the study. The information regarding Anganwadi service utilisation was collected by interviewing mothers using a pilot-tested standardised questionnaire. Other details collected were sex of the child, birth order, maternal education, maternal occupation, type of family, family income, etc. Data was entered using EpiData version 3.1 and analysis was carried out using the Statistical Package for the Social Sciences (SPSS) version 19 software. Statistical measures like mean with standard deviation, frequencies and proportions were used to describe the results. Statistical tests like Pearson Chi-square and Fisher's exact test were used as appropriate to find association. 
Ethical clearance was obtained from the Institutional Ethics Committee. The general health status of the children was assessed by clinical examination and necessary measures including referral were advised. After the study, health education was given to mothers on breastfeeding, immunisation, antenatal care and nutrition.

\section{RESULTS}

In this study, 44 Anganwadi centres in the district were covered. Four hundred and fifty-six (456) children of 3-6 years age group were studied and $54.4 \%$ of them were females. Among the study population, $64 \%$ were Hindus, $33 \%$ Muslims and 3\% Christians. Majority (45\%) belonged to lower middle class (Modified Kuppuswamy Socioeconomic scale 2012). Table 1 shows the educational qualification of mothers (Modified Kuppuswamy scale). Most of the mothers (90\%) were unemployed.

\begin{tabular}{|c|c|}
\hline Maternal Educational Status & Frequency (\%) \\
\hline Professional qualification & $1(0.2)$ \\
\hline Graduate/Postgraduate & $95(21)$ \\
\hline Post high school diploma & $86(19)$ \\
\hline High school & $253(55)$ \\
\hline Middle school & $21(5)$ \\
\hline Total & $456(100)$ \\
\hline
\end{tabular}

Regarding AWC attendance of preschool children in the month prior to the study, $95.2 \%$ of them have attended Anganwadi for more than or equal to 15 days.

The average number of days attended by the children in last month was $20.34 \pm 2.107$. The average number of days of supplementary nutrition consumption in the previous month was $20.34 \pm 2.107$ days.

Of the total three health education classes conducted in last three months, $37.9 \%$ of mothers have attended all the three classes, whereas $10.1 \%$ of mothers didn't attend any (Table 2).

\begin{tabular}{|c|c|}
\hline $\begin{array}{c}\text { Attendance of Health Education Class } \\
\text { by Mothers (Last Three Months) }\end{array}$ & Frequency (\%) \\
\hline Attended all the three classes & $173(37.9)$ \\
\hline Attended two classes & $144(31.6)$ \\
\hline Attended only one class & $93(20.4)$ \\
\hline Did not attend any class & $46(10.1)$ \\
\hline Total & $\mathbf{4 5 6}(\mathbf{1 0 0})$ \\
\hline
\end{tabular}

Table 2. Distribution by Health Education Class Attendance

Reasons for not attending the class: "had personal engagements at that time", "am employed", "had to look after younger child".

In the study, it was found that mothers of female child attended more classes. This difference was statistically significant (Table 3).

\begin{tabular}{|c|c|c|c|c|}
\hline Variables & $\begin{array}{c}\text { Mother } \\
\text { Attended } \\
\text { Two or } \\
\text { More } \\
\text { Classes }\end{array}$ & $\begin{array}{c}\text { Mother Attended } \\
\text { one Class or } \\
\text { didn't Attend any }\end{array}$ & Total & p value \\
\hline $\begin{array}{c}\text { Sex of the } \\
\text { child }\end{array}$ & $135(64.9 \%)$ & $73(35.1 \%)$ & 208 & \\
Male & $183(73.8 \%)$ & $65(26.2 \%)$ & 248 & $0.040^{*}$ \\
Female & & & & \\
\hline
\end{tabular}

Table 3. Factors Associated with Health Education Class Attendance

*Pearson Chi-square test

It was found that there was no significant association between health education class attendance and religion, type of family, socioeconomic status (SES), maternal education or birth order of the child.

Vitamin A was taken at six-month interval by $54 \%$ of children, and $7 \%$ of children have not taken even a single dose of vitamin A (Table 4).

\begin{tabular}{|c|c|}
\hline Vitamin A Consumption & Frequency (\%) \\
\hline Every six months & $247(54)$ \\
\hline More than six months & $178(39)$ \\
\hline Not taken & $31(7)$ \\
\hline Total & $456(100)$ \\
\hline
\end{tabular}

The reasons for low intake of vitamin A: "the vitamin was not available due to shortage of supply" (91.01\%), "had some personal engagements at the scheduled time" (8.98\%).

The present study did not find any significant association with regular intake of vitamin A and either sex of the child, birth order, type of family, SES, maternal education, maternal occupation or health education class attendance.

In the present study, the proportion of children who have taken Albendazole at least once was $70.4 \%$. Only $8.99 \%$ have taken the drug at six-month intervals (Table 5).

\begin{tabular}{|c|c|}
\hline $\begin{array}{c}\text { Variables } \\
\text { (N=456) }\end{array}$ & Frequency (\%) \\
\hline Has taken & $321(70.4)$ \\
\hline Has not taken & $135(29.6)$ \\
\hline $\begin{array}{c}\text { Frequency of Albendazole } \\
\text { Consumption (N = 321) }\end{array}$ & $41(12.77)$ \\
\hline Every six months \\
\hline $\begin{array}{c}\text { More than six months } \\
\text { interval }\end{array}$ & $124(38.62)$ \\
\hline Taken only once & $156(48.59)$ \\
\hline $\begin{array}{c}\text { Place of Obtaining } \\
\text { Albendazole (N =321) }\end{array}$ & $78(24)$ \\
\hline Anganwadi centre & $88(28)$ \\
\hline Another Government centre & $155(48)$ \\
\hline Private sector & Table 5. Distribution by Albendazole Consumption \\
\hline
\end{tabular}

Reasons for not taking Albendazole treatment: "the child did not have any symptoms" (49.6\%), "did not know about the need for taking it" $(50.3 \%)$. 
Of those who have taken Albendazole, $24 \%$ obtained it from the Anganwadi (Table 5).

The study showed that $75.2 \%$ of mothers who have attended two or more health education classes have given their child albendazole at least once and that the association was statistically significant (Table 6).

\begin{tabular}{|c|c|c|c|c|}
\hline Variable & $\begin{array}{c}\text { Gave Albendazole to the Child At least } \\
\text { Once }\end{array}$ & $\begin{array}{c}\text { Deworming not } \\
\text { Done }\end{array}$ & Total & p value \\
\hline Health Education Attendance & $239(75.2 \%)$ & $79(24.8 \%)$ & 318 & $0.001^{*}$ \\
Attended two or more classes & $82(59.4 \%)$ & $56(40.5 \%)$ & 138 & \\
Attended one class or no class & Table 6. Factors Associated with Albendazole Utilisation \\
\hline \multicolumn{4}{|c|}{} \\
\hline
\end{tabular}

*Pearson Chi-square test

Regarding the utilisation of take home ration, $73 \%$ of the preschool children have consumed it when they were less than 3 years old. It was found that factors like sex of the child, type of family, SES, maternal education, maternal occupation and birth order of the child were not statistically associated with utilisation of take home ration.

\section{DISCUSSION}

The present study found that the average number of days of supplementary nutrition consumption in the previous month in the AWC in Kannur district was $20.34 \pm 2.107$ and that 95.2\% preschool children have attended Anganwadi for more than or equal to 15 days in the previous month. ICDS evaluation report 2011 showed that against the norm of 25 days a month, the beneficiaries received food for 16 days a month at national level and 20 days a month at state level in Kerala. 6

Of the total three health education classes conducted in last three months, $37.9 \%$ of mothers have attended all the three classes, whereas, $10.1 \%$ of mothers didn't attend any. The reasons given by the mothers for not attending the class: "had personal engagements at that time", "am employed", "had to look after younger child". In a study by Kanan T Desai et al, the children of mothers who attended health education classes at the Anganwadi had a better nutritional status compared to others. ${ }^{5}$ The mothers have to be motivated to attend the health education sessions as it would increase their awareness regarding nutrition, necessity of nutritional supplementation, immunisation, identification of danger signs in children, etc.

The present study found that Vitamin A was taken at sixmonth intervals by $54 \%$ of children, and $7 \%$ of children have not taken even a single dose of vitamin $\mathrm{A}$. The reasons for low intake of vitamin A as stated by mothers were: "the vitamin was not available due to shortage of supply" (91.01\%), "had some personal engagements at the scheduled time" (8.98\%). The ICDS evaluation 2011 states that AWCs have utilised only $66.7 \%$ of the Vitamin A supplied to them at national level. The Kerala state utilisation of vitamin A was $100 \%$ according to the same report. ${ }^{6}$ Comparing this with the findings in the present study, a gap in the demand and supply of vitamin A was identified. The national coverage of full Vitamin A supplementation in 2012 was $63 \% .^{7}$ In 2012, full Vitamin A supplementation (VAS) coverage above $80 \%$ was achieved in six states but Kerala had extremely low coverage of VAS (20\%). ${ }^{7}$ The present study shows a better coverage in Kannur district compared to state levels, but it is not satisfactory.

The present study showed that in Kannur district, the proportion of children who have taken Albendazole at least once was $70.4 \%$. Only few children (8.99\%) have taken the drug at six-month intervals. Reasons for not taking Albendazole treatment were: "did not have any symptoms" (49.6\%) and "did not know about the need for taking it" (50.3\%). Of those who have taken Albendazole, it was obtained from the Anganwadi centre by only $24 \%$ of children. ICDS evaluation report 2011 states that the percentage of children who received albendazole tablet from the AWC at national level was $56 \%$ and $11.1 \%$ in Kerala. ${ }^{6}$ The present study also reveals an extremely low utilisation of albendazole in Kannur district.

The present study showed that $75.2 \%$ of mothers who have attended two or more health education classes have given their child albendazole at least once and that the association was statistically significant.

About a quarter of the world's population is infected with one or more soil-transmitted worms. ${ }^{8}$ According to WHO, India has the highest burden of Soil-Transmitted Helminths (STH) in the world and 7 in 10 children $<5$ years are anaemic. ${ }^{9}$ Shally Awasthi et al studied the effects on the heights and weights of children $<5$ years residing in urban slums, in Lucknow, North India, of five rounds of Albendazole treatment (400 mg Albendazole) administered every 6 months over 2 years. The results showed that 6 monthly deworming was associated with substantial weight gain in malnourished children. ${ }^{10}$ The present study showed that mothers who have attended the health education classes were more likely to utilise the services from AWC. Anganwadi worker (AWW) and Anganwadi centre (AWC) work for better linkages of the community with the health system. Motivating the mothers to attend the health education classes will improve the utilisation of services delivered through AWCs and thereby improve the health status of children in the long run.

\section{CONCLUSION}

The present study shows that the supplementary nutrition from Anganwadi is properly utilised by the beneficiaries, whereas services like antihelminthic are not fully utilised. The study also revealed a shortage in the availability of vitamin $A$, the beneficiaries were sent back due to lack of supply. These services have a very significant role in improvement of nutritional and health status of children. Measures have to be taken to improve these services in all respects from demand generation to ensuring availability. The proportion of mothers attending health education classes at the centre is also very low. Measures have to be taken to motivate the mothers to attend the classes. 


\section{REFERENCES}

[1] Department of Women and Child Development. Integrated Child Development Services Scheme. 2014. http://wcd.nic.in/icds.htm.

[2] Tandon BN. Nutritional interventions through primary health care: impact of the ICDS projects in India. Bull World Health Organ 1989;67(1):77-80. pdf/bullwho00059-0083.pdf.

[3] Sen P, Bharati S, Som S, et al. Growth and nutritional status of preschool children in India: a study of two recent time periods. Food Nutr Bull 2011;32(2):84-93.

[4] Kapil U, Pradhan R. Integrated Child Development Services scheme (ICDS) and its impact on nutritional status of children in India and recent initiatives. Indian J Public Health 1999;43(1):21-5.

[5] Desai KT, Nayak SN, Patel PB, et al. Follow-up assessment of under-nourished children under integrated child development services scheme in Tapi district, India. Int J Prev Med 2014;5(6):758-66.

[6] Planning Commission of India. Programme evaluation Organization. Evaluation study on Integrated Child Development Schemes (ICDS). PEO Report No. 218. Vol 1.2011.

planningcommission.nic.in/reports/peoreport/peoev alu/peo_icds_v1.pdf.
[7] Scaling Up Vitamin A supplementation in India. Evidence and lessons learned from 15 Major States in India. Nutrition reports. UNICEF. 2014:2. http://unicef.in/Uploads/Publications/Resources/pu b_doc113.pdf.

[8] Taylor-Robinson DC, Jones AP, Garner P. Deworming drugs for treating soil-transmitted intestinal worms in children: effects on growth and school performance. Cochrane Database Syst Rev 2007;(4):CD000371.

[9] National Deworming Day in India: Why is it important? India Today. New Delhi, 2017. http://indiatoday.intoday.in/education/story/nationa l-deworming-day/1/592208.html.

[10] Awasthi S, Peto R, Pande VK, et al. Effects of deworming on malnourished preschool children in India: an open-labelled, cluster-randomized trial. PLoS Negl Trop Dis 2008;2(4): e223. 